\title{
ANALISIS PENETAPAN KEWAJARAN HARGA PADA PEMBIAYAAN RAHN DI BANK MANDIRI SYARI'AH
}

\author{
Emi Rum Hastuti \\ PTA GRESIK \\ emi.rum71@gmail.com
}

\begin{abstract}
ABSTRAK
Fenomena yang dikaji dalam penelitian ini adalah penerapan rahn syariah dalam Bank Mandiri Syariah, dimana para nasabah dalam melakukan transaksi rahn terutama masalah gadai emas secara syari'ah barang yang digadaikan berupa emas dengan kadar 24k kenyataan di bank tersebut hanya dihargai dengan emas kadar 23k, dengan transaksi tersebut jelas ada salah satu yang dirugikan dalam hal ini nasabah, sehingga menguntungkan bagi bank. Berdasarkan fenomena tersebut maka rumusan masalah dalam tesis ini adalah 1) Apakah penetapan harga pada pembiayaan rahn di Bank Mandiri Syariah sudah sesuai dengan kewajaran ? 2) Bagaimana tinjauan hukum ekonomi secara syariah pada pembiayaan rahn di Bank Mandiri Syariah?

Penelitian yang dilakukan dalam tesis ini bersifat analisis deskriptif, Teknik pengumpulan data yang digunakan dalam penelitian ini adalah melalui penelitian kepustakaan dan observasi yang berlokasi di Bank Mandiri Syari'ah cab. Gresik. Bahan hokum dalam penelitian ini adalah Alqur-an dan Al Hadist, serta Undang-undang Nomor 21 tahun 2008 Tentang Perbankan Syarieah, Fatwa DSN Nomor 25/DSN-MUI/III/2002 tentang Rahn, Peraturan Mahkamah Agung RI no.2 tahun 2008 tentang Kompilasi Hukum Ekonomi Syari"ah. Fatwa DSN Nomor 26/DSN-MUI/III/2002 tentang Rahn Emas.

Kesimpulan dari penelitian ini adalah sebagai berikut: 1) Praktek penetapan harga dalam gadai emas / rahn di PT. Bank Syariah Mandiri Cabang Gresik penerima gadai (murtahin) adalah harga versi manajemen PT. Bank Syariah Mandiri yang tidak sesuai dengan standar harga pasaran dari segi kualitas emasnya yakni emas 24 karat milik rahin yang akan digadaikan dihargai sebesar harga emas 23 karat yang sesuai harga pasaran, sehingga tidak sesuai dengan kewajaran harga yang berlaku dipasaran, 2) Menurut Hukum Islam praktek jual beli yang dilakukan PT. Bank Syariah Mandiri, khususnya PT. Bank Syariah Mandiri Cabang Gresik, dengan memperhatikan kaidah Adapun norma atau etika dalam jual beli Islam khususnya dalam hal Menegakkan larangan memperdagangkan barang-barang yang diharamkan, Bersikap benar, amanah dan jujur serta Menegakkan keadilan dan mengharamkan bunga, realitanya terjadi ketidakadilan dari pihak manajemen PT. Bank Syariah Mandiri Cabang Gresik dalam menentukan harga barang rahn emas yang dimiliki oleh konsumen atau rahin di bank tersebut.
\end{abstract}

Kata Kunci : Penetapan, Kewajaran Harga dan Pembiayaan Rahn. 


\section{PENDAHULUAN}

kegiatan konvesional dan syariah

Pembangunan nasional

bertujuan untuk mewujudkan suatu

masyarakat adil dan makmur yang

berdasarkan Pancasila dan UUD

1945. Untuk mewujudkan

masyarakat adil dan berdaulat perlu

ditingkatkan kegiatan perekonomian

yang didukung sector pemerintah

serta kegiatan usaha dari para pelaku

perekonomian.

Keberadaan lembaga

keuangan juga sangat penting untuk

bergerak dalam hal pembiayaan atau

sumber dana guna pelaksanaan

kegiatan perekonomian.

System perbankan di Indonesia diatur dalam UU No. 7

Tahun 1992. Perbankan di Indonesia terdiri dari 2 jenis, yaitu bank umum dan bank perkreditan rakyat. Kedua jenis bank tersebut melaksanakan secara berdampingan (dualbanking system $=$ system perbankan ganda) .

Bank syariaha dalah bank yang melaksanakan kegiatan usaha berdasarkan prinsip Syariah, yaitu aturan perjanjian berdasarkan Hukum Ekonomi Stari'ah. Dalam menjalankan usahanya, bank syariah menggunakan pola bagi hasil yang merupakan landasan utama dalam segala operasinya. Produk-produk bank syariah mempunyai kemiripan tetapi tidak sama dengan bank konvesional, yaitu harus menghindari unsur-unsur yang dilarang.

Bank konvensional bila dihubungkan dengan produk perbankan syariah, maka prodak pembiayaanya adalah sama yang membedakan pada prinsipnya tidak 
mengambil keuntungan sepihak

namun mengunaakan prinsip bagi hasil.

Banyak produk di bank syaria'ah yang akhir akhir ini banyak diminati oleh masyarakat menengah kebawah adalah produk gadai, yang merupakan produk unggulan dalam satu tahun mencapai $85 \%$. Produk gadai emas perhiasan merupakan produk bank syari/ah yang menggunakan akad Rahn, Ijarah dan Qarad.

Produk gadai emas di bank syariah beroperasi didasarkan pada fatwa DSN MUI No 26/DSNMUI/III/2002 gadai emas syariah yang harus memenuhi ketentuan umum sebagai berikut:

a. Rahn emas dibolehkan berdasarkan prinsip rahn

b. Ongkos dan biaya penyimpanan barang (marhun) ditanggung oleh penggadai (rahn)

c. Ongkos penyimpanan besarnya didasarkan pada pengeluaran yang nyatanyata diperlukan

d. Biaya penyimpanan barang (marhun) dilakukan berdasarkan akad ijarah Pada saat pembahasan akad dan perhitungan emas yang digadaikan ada ketentuan dari Bank Mandiri Syariah bahwa emas perhiasan kadar $24 \mathrm{k}$ disamakan harganya dengan emas kadar 23k dengan alasan hal tersebut sudah diatur dari kantor pusat.

Pembiayaan gadai emas di BMS menggunakan akad Rahn sebagai penyerahan jaminan barang berharga berupa emas kepada bank atas pembiayaan yang diterima 
nasabah dan "ijarah" sebagai akadnya.

\section{Bank Mandiri Syariah} menetapkan biaya administrasi dengan mengikuti jumlah gram emas atau metode tiring. Disamping itu pembebanan biaya pemeliharaan juga tidak didasarkan real cost yang diperlukan guna pemeliharaan barang jaminan (gadai).

Carlk R. Abraham dan Mingyuan Zhang menyatakan, seharusnya pembiayaan memenuhi prinsip Fair Lending Compliance (pemenuhan transaksi pinjaman yang seimbang) dimana nasabah tidak dikenakan biaya melebihi biaya sesungguhnya atau biaya yang tidak berkaitan dengan transaksi pembiayaan. 1

Gadai merupakan salah satu kategori dari perjanjian utangpiutang, yang mana untuk suatu kepercayaan dari orang yang berpiutang, maka orang yang yang berhutang menggadaikan barangnya sebagai jaminan pelunasan terhadap utangnya. Perjanjian kredit antara pegadaian dengan penerima kredit (debitur) dituangkan dalam Surat Bukti Kredit (SBK). Ketentuan mengenai gadai diatur dalam $\mathrm{BAB}$ XX Buku II KUH Perdata Pasal 1150 sampai denganPasal 1160.2 Gadai emas pada Bank Mandiri Syari'ah tunduk terhadap undang-undang nomor 21 tahun 2008 tentang Perbankan Syari'ah. Undang-Undang Perbankan Syari'ah tidak mengatur secara materiil mengenai gadai enas, hanya saja mengatur secara formil pada pasal 19 ayat 1 huruf 9 yang isinya Perbankan syari'ah dapat melakukan kegiatan usaha syari,ah lainya asal 
tidak bertentangan dengan prinsip syari,ah.

Prodok gadai emas syari'ah adalah bentuk penyaluran dana dari bank syari'ah yang bertujuan membantu masyarakat dalam hal pemenuhan perekonomian dengan cara yang mudah dan cepat. Namun fenomena yang terjadi sangat menarik untuk ditelaah dari segi ekonomi syari'ah adalah keberadaan dari realita Penetapan Kewajaran Harga dalam Pembiayaan Rahn Syari'ah yang seharusnya mengutamakan keadilan, mendorong kemaslahatan dan meniadakan kezaliman belum terpenuhi.

$$
\text { Kenyataan Penetapan }
$$

kewajaran pembiayaan Rahn di Bank Mandiri Syari'ah tidak memenuhi kreterian tersebut diatas. Dimana para nasabah dalam melakukan transaksi gadai emas dengan mengunakan emas perhiasan kadar 24k hanya dihargai emas perhiasan kadar 23k, dengan transaksi tersebut jelas ada salah satu yang dirugikan dalam hal ini nasabah, sehingga menguntungkan bagi bank.

Pengabilan tarif yang berlebihan dalam hal menyamakan barang gadai berupa emas perhiasan kadar 24k dengan emas perhiasan kadar 23k, lebih dikawatirkan bahwa akad penetapan kewajaran harga rahn tersebut haram dari yang semula halal, sehingga akan tergelincir pada tindakan "hillah".Alasan inilah yang menjadikan persepsi masyarakat terhadap produk bank syari'ah hanyalah sebuah upaya imitasi dari produk bank konvensional. 
PEMBAHASAN

Praktik Gadai Emas di PT. Bank

\section{Syariah Mandiri}

Aktivitas dan pelaksanaan dari praktik gadai emas di PT. Bank Syariah Mandiri dapat dijelaskan dalam sebagai berikut:

1. Syarat dan Ketentuan Produk Pembiayaan Gadai Emas

a. Pembiayaan mulai dari Rp 500.000,00 sampai dengan Rp 500.000.000,00;

b. Jaminan berupa emas (perhiasan atau batangan) minimal 16 karat;

c. Harus emas kuning;

d. Jangka waktu 4 bulan dan dapat diperpanjang maksimal dua kali; e. Memiliki rekening di BSM.

2.. Manfaat dan Kemudahan

Produk Pembiayaan Gadai

Emas :

a. Aman dan terjamin

b. Prosesnya mudah dan cepat

c. Biaya pemeliharaan yang kompetitif

d. Terkoneksi dengan rekening tabungan

3. Persyaratan pembiayaan

a. Perorangan

b. Badan usaha

4. Karakteristik :

a. Berdasarkan prinsip syariah dengan akad qardh dan rahn

b. Biaya administrasi barang jaminan dibayar pada saat pencairan 
c. Biaya pemeliharaan

dihitung per bulan dan

dibayar pada saat

pelunasan.

Prosedur

untuk

memperoleh fasilitas pembiayaan

gadai emas di Bank Syariah Mandiri

tidak sulit. Berdasarkan wawancara

yang tidak tersetruktur dengan

Bapak Bhayu Kurniawan pada

Selasa,17 Januari 2017 pukul 13.00

wib, prosedurnya sebagai berikut :

1. Calon nasabah datang langsung ke Bank Syariah Mandiri dengan membawa emas yang berupa perhiasan ataupun batangan dengan menunjukkan persyaratan pembiayaan yang telah ditentukan. Jika persyaratan yang dibawa oleh calon nasabah sudah lengkap, kemudian nasabah mengisi formulir permohonan gadai yang telah disediakan.

2. Barang jaminan emas tersebut diteliti kualitasnya oleh petugas gadai untuk menetapkan nilai pembiayaan yang akan diberikan. Nilai pembiayaan yang diberikan jika perhiasan sebesar $85 \%$ dari nilai taksiran sedangkan jika batangan sebesar $90 \%$ dari nilai taksiran.

3. Petugas gadai menaksir harga emas yang digadaikan. Setelah itu petugas gadai menguji keaslian barang jaminan emas dengan langkah-langkah yang sudah ditentukan.

4. Kemudian, petugas gadai melakukan komite ke kantor cabang untuk menentukan diterima atau ditolaknya pembiayaan tersebut. Setelah 
keputusan dari cabang

diterima oleh petugas gadai, maka petugas gadai akan menginformasikan kepada calon nasabah.

5. Jika diterima, maka petugas gadai akan menghitung pembiayaan yang akan diterima oleh calon nasabah sesuai ketentuan BI sekaligus menentukan biaya administrasi.

6. Kemudian pencairan disertai dengan pembayaran biaya administrasi secara tunai sesuai dengan yang telah ditentukan.

Prosedur Penaksiran Barang Gadai emas

$$
\begin{aligned}
& \text { Barang jaminan } \\
& \text { emas yang diserahkan oleh } \\
& \text { calon nasabah untuk } \\
& \text { digadaikan ditaksir terlebih }
\end{aligned}
$$

dahulu oleh petugas gadai yang sudah mempunyai keahlian khusus.

Berdasarkan wawancara yang tidak tersetruktur dengan Bapak Bhayu Kurniawan pada 17 Januari 2017 pukul 13.30 wib, pedoman penaksirannya sebagai berikut :

1. Petugas gadai melihat Standar Harga Emas yang ditetapkan oleh Divisi Usaha Syariah. Standar Harga Emas tersebut selalu disesuaikan dengan perkembangan harga pasar emas.

2. Petugas gadai melakukan penentuan karatase dan berat emas dengan menggunakan metode uji 
kimia dan berat jenis, yaitu :

a. Metode jarum uji emas

1) Jarum uji emas

2) Batu uji

3) Larutan uji emas yaitu asam nitrat dan asam chlorida.

4) Loupe (kaca pembesar) $10 \mathrm{x}$

5) Botol air uji emas yang berwarna gelap

6) Gelas ukur kimia untuk takaran campuran zat kimia.

7) Pipet tetes dan kertas tissue

b. Metode berat jenis

Alat-alat $\quad$ yang
digunakan $\quad$ dalam

metode ini antara lain :
1)

Timbangan

(elektronik

atau

manual)

2) Gelas ukur atau

bejana tempat air

3) Air murni

4) Tempat timbangan emas atau tali pengikat

1. Petugas gadai menentukan nilai taksiran dan pembiayaan sesuai dengan ketetapan Bank Syariah Mandiri

Dengan rumus :

Nilai Taksiran $=$ berat emas x harga emas saat ini

Maksimal pembiayaan yang diberikan

- Batangan $=90 \% \times$ nilai taksiran

- Perhiasan $=85 \% \times$ nilai taksiran 
Pembiayaan tergantung permintaan nasabah

Biaya pemeliharaan :

- Batangan $=1,24 \% \mathrm{x}$ nilai taksiran

- Perhiasan $=1,33 \% \mathrm{x}$

nilai taksiran

Biaya administrasi :

Jangka waktu 4 bulan 
Tabel 3.3

Tabel Biaya Administrasi

\begin{tabular}{|c|c|}
\hline $\begin{array}{c}\text { Nilai Taksiran } \\
\text { (dalam juta) }\end{array}$ & Biaya \\
& Administrasi \\
\hline $1-5$ & 18.000 \\
\hline $5-10$ & 25.000 \\
\hline $10-20$ & 35.000 \\
\hline
\end{tabular}

Keterangan :

Biaya administrasi termasuk biaya asuransi telah ditentukan oleh pihak penerima gadai.

Pada saat pencairan, nasabah harus membayar biaya administrasi secara tunai.

Selanjutnya akan dilakukan simulasi

perhitungan gadai emas perhiasan yang sudah dilakukan antara nasabah dengan pihak Bank Syariah Mandiri Cabang Gresik.

Misalnya seorang nasabah pada tanggal 22 Nopember 2016, dengan Surat Bukti Gadai Emas (SBGE) nomor 048R5272LD1632, dengan transaksi menggadaikan emasnya berupa perhiasan satu buah cincin, dengan kadar 24 karat dihargai emas 23 karat dan berat 6,11 gram.

Jika nasabah melunasi pinjamannya pada tanggal 22 Maret 2017, berapakah biaya pemeliharaan yang harus dibayarkan

HDE atau Harga Dasar Emas saat itu adalah Rp 509.500,Saat ini taksiran harga emas bagi pembiayaan gadai bukanlah berdasarkan harga jual emas batangan dipasaran, melainkan berdasarkan harga taksiran yang telah ditentukan oleh managemen pusat BSM. Selanjutnya transaksi agunan dilakukan sesuai dengan aturan bank Indonesia maksimal $80 \%$ hari harga jaminan. 
Harga emas sebesar 1

gram yang bersertifikat ANTAM

dengan kriteria 24 karat adalah

sebesar Rp. 526.000

Pihak PT. Bank Syariah

Mandiri memberikan taksiran

untuk emas 6 gram 24 Karat

tersebut senilai emas 6 gram 23

karat, asumsi Harga per gram : Rp.

$509.500 \quad$ (sesuai ketentuan

manajemen pusat),

Kualitas dan jenis emas

tersebut sangat mempengaruhi

jumlah nominal pembiayaan yang

akan diberikan kepada nasabahnya.

Selain itu, besaran nilai ujroh yang

dibebankan nasabah kepada Bank

ditentukan berdasarkan berat jenis

emasnya dan besaran Qard adalah

total harga taksiran emas x $80 \%$.

Semakin besar berat

emas yang digadaikan, maka

semakin murah biaya yang dibayar.
Perjanjian gadai berlangsung

maksimal 4 bulan, selanjutnya

nasabah diberikan opsi untuk

melakukan pelunasan, ataupun

perpanjangan gadai.

\subsubsection{Konstruksi}

Kontrak/Akad Gadai Emas

dalam pandangan Fiqih

Praktik gadai emas

merujuk pada Fatwa DSN NO 26.

DSN-MUI/III/2002. Pada ayat

ketiga dalam fatwa DSN No.26

tentang gadai emas menjelaskan

bahwa nasabah penggadai

menanggung semua biaya

pemeliharaan yang besarnya

berdasarkan pengeluaran yang

nyata.

Praktik akad Qard, Rahn, dan ijarah dalam satu akad gadai emas yang dilakukan oleh Bank syariah dalam pandangan peneliti bertentangan dengan fiqh, karena 
tidak memperdulikan keadilan

dalam menilai karat yang menyamakan emas $24 \mathrm{k}$ dengan emas $23 \mathrm{k}$.

Dalam Islam kesesuain akad fiqih dengan mekanisme produk di lembaga keuangan syariah akan berpengaruh terhadap kehalalan produk tersebut. Begitu pula dalam penetapan harga atas sebuah transaksi akan sangat dipengaruhi oleh ijab qobul yakni masing masing pihak menyatakan persetujuannya atas aturan aturan dalam kontrak dan kerelaannya yang direpresentasikan melalui hak khiyar sebagai mekanisme yang menunjukkan adanya kebebasan masing masing pihak dalam menyetujui akad.

Berdasarkan analisa di atas, maka penggabungan Akad Rahn dan Akad Qardh dengan menggunakan nama Akad Pinjaman dengan Gadai (Rahn) dan atau Akad Qardh dalam rangka Rahn dalam produk Gadai Emas Mandiri Syari'ah adalah keliru dan tidak sesuai dengan Syariah yang mengharuskan adanya kejelasan dalam maksud akad.

Keabsahan akad dalam produk lembaga keuangan syariah dan mekanisme adalah hal yang wajib. Disamping itu produk dan mekanisme Lembaga Keuangan Syariah harus seiring dengan etika dan nilai-nilai keadilan . Untuk itu akad dalam pembiayaan syariah harus memiliki unsur-unsur sebagai berikut :

1. Transparansi akad. Kejelasan akad merupakan aspek legalitas dalam suatu produk, diwujudkan dalam bentuk ijab qobul. Ijab Qobul ini merangkum 
adanya pengetahuan akan hak dan kewajiban antara LKS dan nasabah.

2. Transparansi obyek transaksi dan kesesuaian dengan syariat

3. Transparansi dalam pengetahuan sistem dan Mekanisme penentuan Harga.

\section{Keadilan dan}

Keseimbangan

Itulah beberapa alternatif yang bisa dijalankan guna mengeliminir praktek riba dalam pegadaian konvensional. Dan juga sebagai solusi atas persoalan yang terdapat dalam pegadaian saat sekarang ini, sehingga diharapkan natinya lembaga ini benar-benar telah menjalankan mottonya sebagai lembaga yang mengatasi masalah tanpa menimbulkan masalah.[17]

\section{A. Analisis Penelitian}

Berdasarkan temuan data dalam penelitian ini khusunya yang menyangkut fenomena yang dikaji secara ilmiah dari tinjauan hukum yakni penentuan dari nilai kadar kualitas karat pada logam mulia emas perhiasan yang ditetapkan oleh pihak manajemen. Penetapan kewajaran harga dalam pembiayan rahn syariah adalah harus sesuai dengan ketentuan ekonomi syariah yang mana harus mengutamakan keadilan, mendorong kemaslahatan serta meniadakan kezaliman. Dalam kenyataanya penerapan rahn syariah dalam Bank Mandiri Syariah tidak memenuhi kreteria sebagaimana tersebut diatas dimana para nasabah dalam melakukan transaksi rahn terutama masalah gadai emas secara syari'ah barang yang digadaikan berupa emas perhiasan dengan 
kadar 24k kenyataan di bank tersebut hanya dihargai dengan emas kadar 23k, dengan transaksi tersebut jelas ada salah satu yang dirugikan dalam hal ini nasabah, sehingga menguntungkan bagi bank.

Setelah menganalisa emas perhiasan dengan kadar $24 \mathrm{~K}$ dihargai $23 \mathrm{k}$ karena pihak bank mengunakan prinsip kehati-hatian (menejeman resiko) dimana harga tersebut ditetapkan dengan asumsi apabila nasabah tidak bisa melunasi hutangnya, maka barang jaminan dapat dipakai melunasi hutang tersebut dan masih ada sisa penjualan yang dikembalikan pada Rahin.

Oleh karena itu penelitian ini akan menganalisis fakta yang terjadi tersebut akan merugikan masyarakat dan lebih khawatirkan lagi bahwa akad dalam penetapan harga tersebut menjadi haram dari yang semula halal karena ketentuan penetapan kewajaran harga tersebut yang tidak sesuai dengan barang yang digadaikan membuat akad menjadi tidak sah karena ada salah satu pihak terdzalimi.

Keabsahan akad dalam produk lembaga keuangan syariah dan mekanisme adalah hal yang wajib. Disamping itu produk dan mekanisme Lembaga keuangan syariah harus seiring dengan etika dan nilai-nilai keadilan, sebagaimana dalam bersumber pada al-Qur'an surat (83): 1-3 yang menjelaskan tentang penguranggan nilai takaran.

Pada transaksi rahn dengan produk emas perhiasan di PT. Bank Mandiri Syariah Cabang Gresik ini yang menetapkan harga secara mutlak adalah pihak 
perbankan (PT. Bank Mandiri

Syariah). Seyogyanya penetapan harga yang sepihak itu memperhatikan kemampuan dan kewajaran harga pasar dengan sesuai kualitas yang diterima oleh kewajaran harga pasar

Pada kegiatan jual beli secara syariah menekankan harus berada di bawah prinsip keadilan dan mencegah kezaliman, sehingga kegiatan yang melanggar keadilan dan mendatangkan kezaliman dilarang oleh Islam seperti monopoli, menimbun barang, eksploitasi dan perdagangan yang tidak sah lainnya. Sebagaimana firman Allah dalam Al-Qur'an Surat An-nahl ayat 90 yang memerintahkan agar manusia berlaku adil, yang artinya sebagai berikut:

"Sesungguhnya Allah menyuruh (kamu) Berlaku adil dan berbuat kebajikan, memberi kepada kaum kerabat, dan Allah melarang dari perbuatan keji, kemungkaran dan permusuhan. Dia memberi pengajaran kepadamu agar kamu dapat mengambil pelajaran."

Dari ayat di atas Allah telah menjelaskan bahwa setiap manusia harus bersikap adil kepada siapapun, seperti halnya dalam jual beli, setiap penjual harus berlaku adil kepada pembeli.

Kesemuanya itu menguatkan praktek rahn khususnya di PT. Bank Syariah Mandiri Cabang Gresik betapapun menjalankan bisnis secara adil, sesuai dengan hukum yang berlaku.

\section{Kesimpulan}

1. Praktek penetapan harga dalam gadai emas / rahn di PT. Bank Syariah Mandiri Cabang Gresik penerima gadai (murtahin) adalah harga versi manajemen PT. Bank Syariah Mandiri yang tidak

1 Departemen Agama RI, AlQur'an dan Terjemahnya, hlm.172 
sesuai dengan standar harga pasaran dari segi kualitas emasnya yakni emas perhiasan 24 karat milik rahin yang akan digadaikan dihargai sebesar harga emas perhiasan 23 karat yang sesuai harga pasaran, sehingga tidak sesuai dengan kewajaran harga yang berlaku dipasaran, yang seharusnya barang gadai tetap dinilai emas perhiasan 24k dengan harga pasaraan pada saat terjadinya akad, sekalipun pembiayaan diberikan sebesar $85 \%$

\section{Menurut Hukum}

Ekonomi Syari'ah praktek jual beli yang dilakukan

PT. Bank Syariah Mandiri Cabang Gresik, khususnya mengenai gadai emas perhiasan, dengan memperhatikan kaidah dan norma atau etika dalam jual beli secara ekonomi syariah belum terpenuhinya prinsip syari'ah, yaitu mengutamakan kemaslahatan, menegakkan keadilan serta meniadakah kezaliman. Karena adanya ketimpangan harga dalam penetapan barang gadai berupa emas perhiasan dengan menyamakan harga emas perhiasan $24 \mathrm{k}$ dengan emas 23k, realitanya terjadi ketidakadilan dari pihak manajemen PT. Bank Syariah Mandiri Cabang Gresik, sehingga lebih menguntungkan pihak bank dan merugikan nasabah.

\section{Saran}

1. Bagi PT. Bank Syariah Mandiri Cabang Gresik

a. Bagi manajemen PT. Bank Syariah Mandiri Cabang Gresik lebih baik mencamtumkan penentuan harga barang gadai (emas) secara jujur dan transparan, sehingga rahin benar-benar menyadari dan tidak merasa terpaksa dalam melakukan akad 
gadai di PT. Bank Syariah Mandiri

Cabang Gresik.

b. Bagi PT. Bank Mandiri

Syariah Cabang Gresik khususnya

staff pemasaran dan customer

service, hendaknya berbuat jujur

dengan tidak memanfaatkan ketidak

tahuan para calon rahin berkaitan

dengan penentuan harga emas yang

digadaikan di lembaganya, sehingga

tidak menimbulkan persepsi atau

menghindari kesan memanipulasi

harga.

c. Bagi manajemen PT.

Bank Syariah Mandiri Cabang

Gresik hendaknya bertransaksi

selain bertujuan untuk mencari

keuntungan juga dapat menolong

bagi warga dan masyarakat umum,

dan menerapkan prinsip syari'ah

secara nyata.
2. Bagi Rahin,

Hendaknya sebelum

melakukan akad rahn barang emas

hendaknya terlebih dahulu

menanyakan harga yang diterima

dan mendapat informasi yang

sejelas-jelasnya sehingga harga bisa

disepakati sebelum melakukan akad

rahn dengan manajemen PT. Bank

Syariah Mandiri Cabang Gresik. 